\title{
Neuropeptide tyrosine (NPY): a newly discovered peptide is present in the mammalian respiratory tract
}

\author{
MN SHEPPARD, JM POLAK, JM ALLEN, SR BLOOM \\ From the Departments of Histochemistry and Medicine, Royal Postgraduate Medical School, Hammersmith \\ Hospital, London
}

\begin{abstract}
Neuropeptide tyrosine (NPY), a newly discovered peptide known to modulate blood vessel diameter and smooth muscle tone, has been found in many mammalian organs. Its distribution is similar to that of sympathetic nerve fibres and NPY immunoreactivity has been found in noradrenergic ganglion cells. In a study of the respiratory tract of four mammalian species-man, cat, guinea pig, and rat-NPY immunoreactivity has been localised to nerve fibres. NPY immunoreactive nerve fibres were found in the adventitia of blood vessels and in the airway smooth muscle. Its distribution was strikingly similar to that of sympathetic nerve fibres as demonstrated by dopamine- $\beta$-hydroxylase antibodies. The mean (SD) concentrations of NPY in the guinea pig respiratory tract, as determined by radioimmunoassay of tissue extracts, were: upper trachea $3.3(0.7)$, lower trachea $2.0(0.5)$, and major bronchus $3.5(1 \cdot 1) \mathrm{pmol} / \mathrm{g}$. During developmental studies in man NPY immunoreactive nerve fibres were first observed at 20 weeks' gestation in the trachea, and fibres gradually extended down into the intrapulmonary airways after birth. NPY immunoreactive nerve fibres have a distribution and developmental pattern similar to that of sympathetic nerve fibres in the respiratory tract. The finding of NPY immunoreactivity in nerve fibres in the mammalian respiratory tract adds to the growing number of peptides having potent biological actions found in this organ, and shows that the lung possesses a rich peptidergic system, which may influence pulmonary function.
\end{abstract}

A chemical assay for C-terminal amides recently isolated from porcine brain neuropeptide tyrosine (NPY-the Y representing tyrosine), which has 36 amino acids. ${ }^{12}$ The peptide shares sequence homology with two other peptides-pancreatic polypeptide (PP), secreted by PP cells of the mammalian pancreas; and peptide YY (PYY), localised to endocrine cells of the ileum and colon. ${ }^{3}$

NPY has been found by both radioimmunoassay and immunocytochemistry in high concentrations within nerve fibres in the mammalian brain ${ }^{14}$ and heart. ${ }^{56}$ NPY immunoreactivity has been found in sympathetic ganglia and in nerve fibres in the adventitia of blood vessels and in the smooth muscle of the vas deferens and gastrointestinal tract of man, cat, pig, guinea pig, and rat. ${ }^{78}$ In these organs the distribution of NPY immunoreactive nerve fibres is

Address for reprint requests: Dr JM Polak, Department of Histochemistry, Royal Postgraduate Medical School, Hammersmith Hospital, London W12 OHS.

Accepted 8 February 1984 very similar to that of sympathetic nerves, and NPY immunoreactive ganglion cells have also been found to contain tyrosine hydroxylase and dopamine- $\beta$ hydroxylase $(\mathrm{D} \beta \mathrm{H}) .^{679}$ In addition, a reduction in the level of NPY immunoreactivity has been reported in the rabbit and the guinea pig eye after sympathectomy. ${ }^{1011}$

Recently many potent bioactive peptides have been found in the mammalian respiratory tract. ${ }^{12}$ Vasoactive intestinal polypeptide (VIP) and substance $P$ are found in the lung innervation,,$^{13} 14$ while bombesin and calcitonin are localised to mucosal endocrine cells. ${ }^{1516}$ Other peptides, including cholecystokinin and somatostatin, have also been detected within the respiratory tract by radioimmunoassay. ${ }^{17}$ In view of the fact that several of the peripheral regulatory peptides are found within both nerves and cells in the respiratory tract, we decided to investigate the presence of the newly isolated neuronal peptide NPY in the mammalian respiratory tract and compare its distribution to that of sympathetic nerve fibres. We have also studied the 
developmental pattern of nerve fibres containing NPY in the human lung.

\section{Methods}

Respiratory tissue was obtained from 15 human adults (seven male and eight female, aged 18-88 years) dying of non-cardiopulmonary causes, obtained within 12-18 hours of death. In each case, the areas dissected out included the trachea and major bronchi, the inner lung zone containing minor bronchi, the middle lung zone containing medium sized bronchi, and the outer lung zone including alveoli. Areas similar to those dissected out of the adult human respiratory tract were also obtained from 11 adult cats (five female and six male, 2.9-4.2 kg, aged 15-24 months), eight Wistar rats (all female, 190-250 g, aged 3-4 months), and six Dunkin Hartley guinea pigs (four male and two female, 250-450 g, aged 4-6 months). The animals were killed by cervical dislocation (rat and guinea pig) or with an intraperitoneal injection of sodium pentobarbitone (cat).

For developmental studies, the respiratory tract was taken from fresh human abortuses (less than 6 hours old), whose gestational age was estimated by foot length in dismembered fetuses ${ }^{18}$ and crownrump length in intact fetuses. ${ }^{19}$ The fetuses were divided into two groups on the basis of gestational age and stage of lung development: ${ }^{20} 7-16$ weeks (glandular stage; $n=19$ ) and 17-24 weeks (canalicular stage; $n=11$ ). Respiratory tissue was also obtained from human neonates $(n=9)$ and infants aged from 6 weeks to 6 years $(n=4)$ dying of non-cardiopulmonary causes. In the fetal respiratory tract the areas dissected out included trachea, major bronchi, and inner and outer lung zones. In the postnatal specimens the areas dissected out were similar to those of the human adult. Each specimen of respiratory tract from all four species was subdivided and processed for immunocytochemistry and radioimmunoassay.

\section{IMMUNOCYTOCHEMISTRY}

Fixation Each piece of respiratory tract, measuring $1 \times 0.75 \times 0.5 \mathrm{~cm}$, from all four species was processed as follows. Fresh tissue was fixed in parabenzoquinone solution $(0.4 \mathrm{~g}$ benzoquinone: $100 \mathrm{ml} 0.01$ mol/l phosphate buffered saline (PBS), $\mathrm{pH} 7.4$ ) for one and a half hours at $4^{\circ} \mathrm{C} .^{21}$ After fixation the tissue was washed overnight in buffered sucrose $(70$ $\mathrm{mg} / \mathrm{ml}$ sucrose, $0.1 \mathrm{mg} / \mathrm{ml}$ sodium azide in PBS) and then made into cryostat blocks and sectioned at a thickness of $10 \mu \mathrm{m}$ in a cryostat at $-20^{\circ} \mathrm{C}$.

Technique The indirect immunofluorescence technique $^{22}$ was applied to the sections, antibodies to natural porcine NPY conjugated to bovine serum albumin with bis-diazobenzidine being used. NPY antibodies were used at a dilution of 1:600. Preabsorption of the antiserum with pure or synthetic NPY at a concentration of $1.0 \mathrm{nmol} / \mathrm{ml}$ of diluted antibody completely abolished immunostaining, whereas the addition of pure or synthetic PYY, PP, VIP, or substance $P$ at concentrations above 30 $\mathrm{nmol} / \mathrm{ml}$ of diluted antibodies had no effect on the immunostaining. Antibodies to dopamine- $\beta$ hydroxylase were kindly provided by Dr RA Rush of Flinders Medical School, Australia, and used at a dilution of 1:2000. Negative controls included normal rabbit serum at a dilution of $1: 2000$ and fluorescein-isothiocyanate conjugate (FITC) alone.

\section{RADIOIMMUNOASSAY}

For radioimmunoassay, the NPY content of guinea pig respiratory tract was extracted by boiling weighed tissue in $0.5 \mathrm{~mol} / \mathrm{l}$ acetic acid $(10 \% \mathrm{w} / \mathrm{v})$. NPY concentrations in these extracts were determined with an antibody ( $\mathrm{YNI}$ ) raised in rabbit to natural porcine NPY conjugated to bovine serum albumin with carbodiimide. Natural porcine NPY was iodinated by chloramine $\mathrm{T}$ oxidation and purified on a G50 superfine column before use as tracer in the assay. The antibody was used in a final dilution of 1:10 000 in an assay volume of $600 \mu l 0.06$ $\mathrm{mmol} / \mathrm{l}$ sodium phosphate buffer, $\mathrm{pH} 7 \cdot 2$, containing $1 \%$ bovine serum albumin. Twenty microlitre aliquots of extracts were assayed in duplicate. Pure porcine NPY was used as standard. The assay could detect 2 fmol per assay tube with $95 \%$ confidence.

\section{Results}

\section{IMMUNOCYTOCHEMISTRY}

NPY-like immunoreactive nerves were seen throughout the adult respiratory tract of all four species studied. Fine varicose fibres were located chiefly in the adventitia of tracheobronchial and pulmonary blood vessels, both arteries and veins, down to the level of the capillaries (fig 1). NPY immunoreactive fibres were also seen in the airway smooth muscle from the trachea down to the level of the bronchioles (fig 2), but diminished in density towards the bronchioles. Although ganglion cells were present in the respiratory tract of all species, particularly in the adventitia of the tracheobronchial wall, none of these ganglion cells was immunoreactive for NPY. $D \beta H$ immunoreactive nerve fibres have a strikingly similar distribution to NPY containing nerve fibres, being located chiefly around blood vessles and in airway smooth muscle (figs 3 and 4).

In the human fetal respiratory tract NPY 


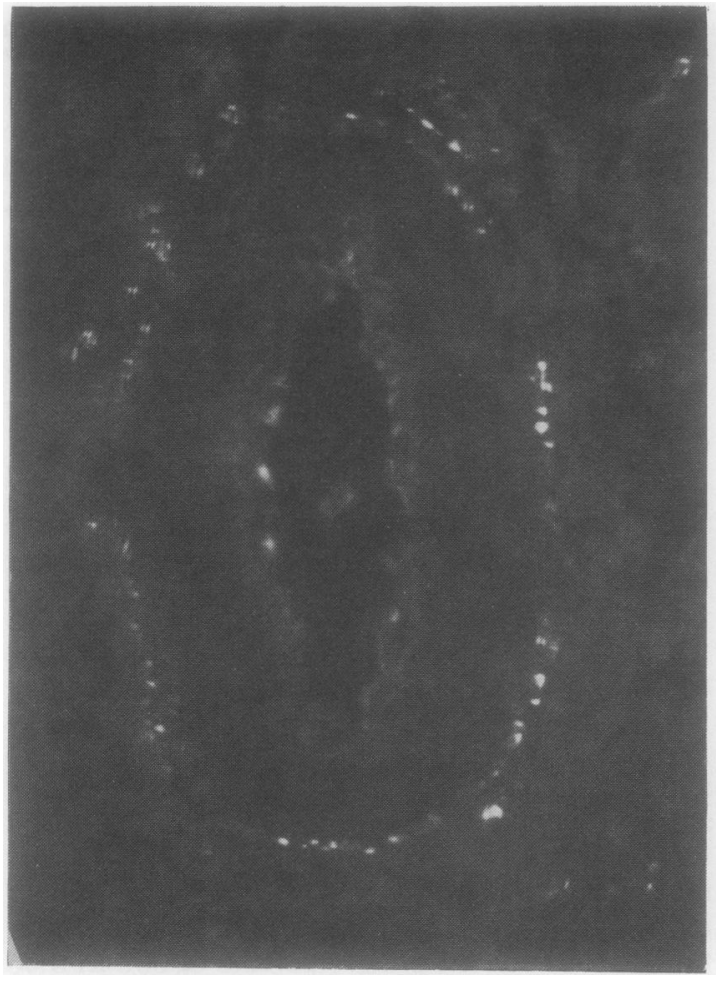

Fig 1 Neuropeptide tyrosine (NPY) immunoreactive nerve fibres in the adventitia of a pulmonary artery in the rat lung. (Indirect immunofuorescence, $\times 400$.)

immunoreactive nerve fibres were first observed in the smooth muscle and blood vessels of the trachea and major bronchi at 20 weeks' gestation (late canalicular stage). After birth NPY containing nerve fibres extended into the intrapulmonary airways and blood vessels and their distribution was similar to that in the adult. Interestingly, $\mathrm{D} \beta \mathrm{H}$ immunoreactive nerve fibres were also first observed at 20 weeks and followed a developmental pattern similar to that of NPY containing nerve fibres.

\section{RADIOIMMUNOASSAY}

The highest concentrations of extractable NPY were found in the upper trachea (3.3 (SD 0.7) pmol/g) and major bronchi $(3.5(1.1) \mathrm{pmol} / \mathrm{g})$, whereas lower concentrations were identified in the lower trachea $(2.0(0.5) \mathrm{pmol} / \mathrm{g})$ and middle lung $(1.2$ $(0.5) \mathrm{pmol} / \mathrm{g})$. NPY concentrations were below the detection limit of the assay (that is, $<0.5 \mathrm{pmol} / \mathrm{g}$ ) in the nasal mucosa, inner lung, and outer lung.

\section{Discussion}

The results show that the newly isolated peptide

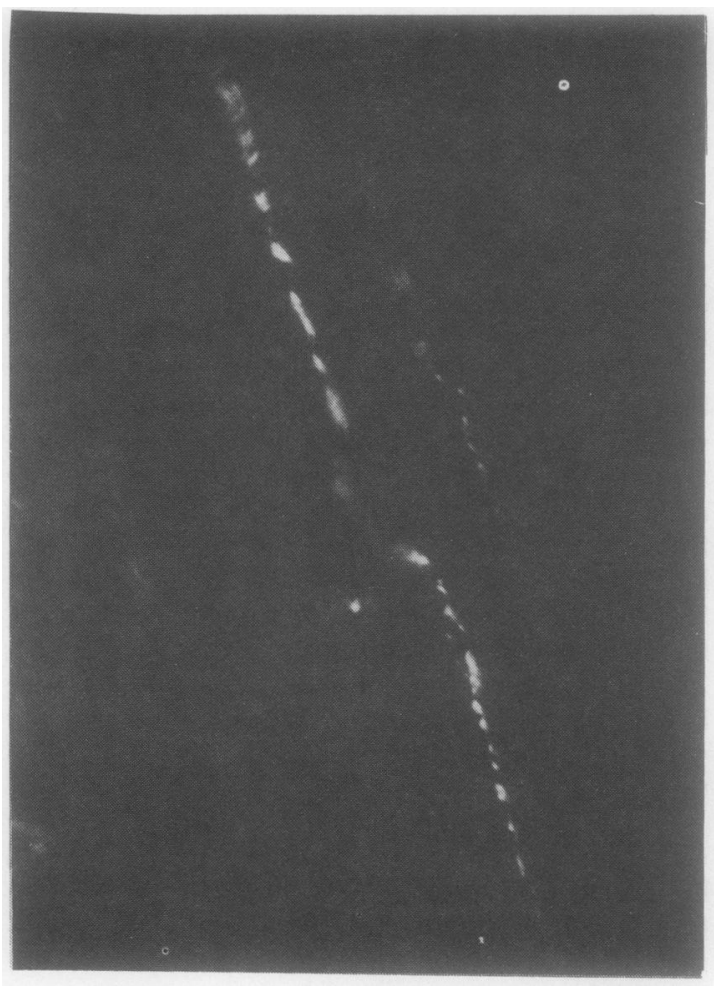

Fig 2 Fine varicose NPY immunoreactive nerve fibres in the trachealis smooth muscle of adult human trachea. (Indirect immunoftuorescence, $\times 450$.)

NPY is present in the adult mammalian respiratory tract. The localisation of NPY immunoreactivity to nerve fibres around blood vessels and smooth muscle in the respiratory tract is interesting in view of the known actions of this peptide. NPY is a potent vasoconstrictor in the cat ${ }^{17}$ and in the rabbit heart NPY reduces myocardial perfusion and inhibits the force of myocardial contraction. ${ }^{23}$ It inhibits the electrically induced contraction of non-vascular smooth muscle in rat and mouse. ${ }^{24}$ NPY therefore adds to the growing number of known bioactive peptides in the respiratory tract. Our findings also show that NPY has a similar distribution to that of nerve fibres containing $\mathrm{D} \beta \mathrm{H}$.

In an earlier study ${ }^{25}$ of the respiratory tract of man, cat, guinea pig, and rat, antibodies to the enzyme neurone specific enolase (NSE) were used as a general marker for ganglion cells and nerve fibres. It was established that in serial sections the distribution of $\mathrm{D} \beta \mathrm{H}$ positive nerve fibres was similar to that of NSE immunoreactive nerves, but that NSE containing nerves were present in much greater numbers around blood vessels and in smooth muscle. In the present study NSE immunostaining was 


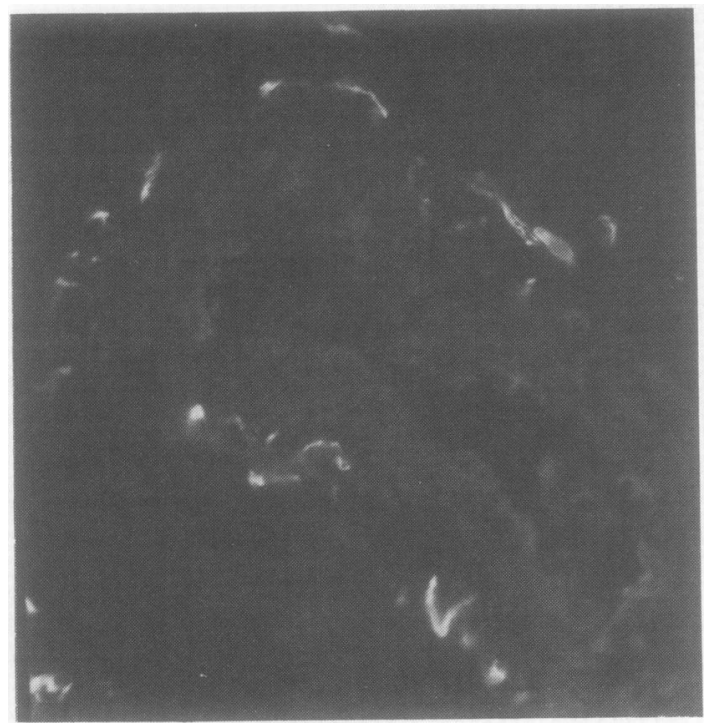

Fig 3 Dopamine- $\beta$-hydroxylase immunoreactive nerve fibres in the adventitia of a venule in rat lung. (Indirect immunofuorescence, $\times 360$.)

also carried out and gave results similar to those previously reported..$^{25}$ The distribution of NSE containing nerves was similar to that of NPY containing nerves, but NSE containing nerves were much more abundant. In the study already mentioned ${ }^{25}$ it was proposed that, since NSE immunostaining showed

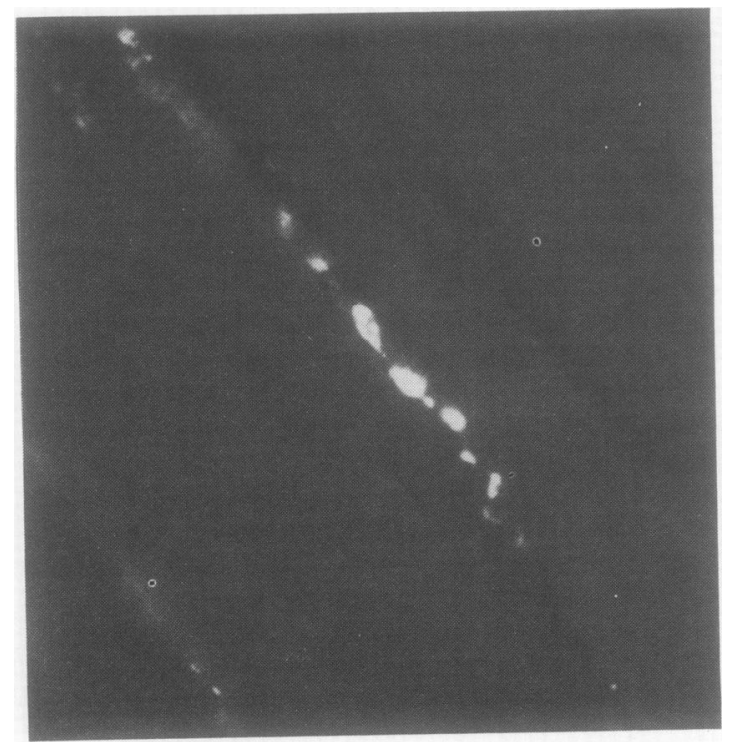

Fig $4 D \beta H$ immunoreactive nerve fibres in tracheal smooth muscle of human adult trachea. (Indirect immunofuorescence, $\times 500$.) more ganglion cells and nerve fibres in the respiratory tract than previous methods, other nerve cells and fibres must be present in the respiratory tract, whose neurotransmitter remained to be identified. The finding of NPY immunoreactivity in nerves in the respiratory tract confirms this. It is technically impossible at the level of light microscopy to state with certainty whether NSE is present in NPY containing nerves or if $D \beta H$ is colocalised with NPY in the same nerve fibres, since with serial sectioning we can never be certain that the same nerve or another nerve present in the same bundle is being sectioned. Since no NPY containing ganglion cells were identified in the respiratory tract of any species, we were unable to carry out colocalisation studies on ganglion cells in the manner of our earlier study. ${ }^{25}$ We can only state that NSE containing and $D \beta H$ containing nerve fibres had a distribution exactly similar to that of NPY containing nerves.

In another study we have established the developmental pattern of peptides and classical neurotransmitters in the human respiratory tract. ${ }^{26}$ NPY immunoreactive nerve fibres appear at the same time as $D \beta H$ containing nerve fibres (20 weeks); whereas cholinergic ganglion cells and nerve fibres, as demonstrated by the acetylcholinesterase technique, develop earlier (12 weeks). This suggests a close relationship between NPY containing and sympathetic nerve fibres in the respiratory tract. The fact that NPY immunoreactivity has been found in noradrenergic ganglion cells ${ }^{679}$ suggests a co-storage of the peptide with noradrenaline. The vasoconstrictor action of NPY is similar to the action that follows stimulation of sympathetic nerves, ${ }^{7}$ and the relaxation induced in mouse vas deferens by NPY may be due to modulation of noradrenaline release. ${ }^{23}$ Further investigations are necessary to define the full role of this newly discovered neuropeptide in the respiratory tract. Immunostaining at the electron microscope level should enable us to establish whether NPY is colocalised with $D \beta H$ in the same nerve fibres.

This work was supported by the Council for Tobacco Research (USA). MNS and JMA are in receipt of Wellcome Trust research fellowships.

\section{References}

' Tatemoto K, Carlquist M, Mutt V. Neuropeptide Y-a novel brain peptide with structural similarities to peptide YY and pancreatic polypeptide. Nature 1982;296:659-62.

${ }^{2}$ Tatemoto K. Neuropeptide $Y$ : complete amino acid sequence of the brain peptide. Proc Natl Acad Sci 1982;79:5485-9. 
${ }^{3}$ Tatemoto $\mathrm{K}$. Isolation and characterization of peptide YY (PYY), a candidate gut hormone that inhibits pancreatic exocrine secretion. Proc Natl Acad Sci 1982;79:2514-8.

${ }^{4}$ Allen YS, Adrian TE, Allen JM, et al. Neuropeptide Y distribution in the rat brain. Science 1983;221:877-9.

${ }^{5} \mathrm{Gu}$ J, Adrian TE, Tatemoto K, Polak JM, Allen JM, Bloom SR. Neuropeptide tyrosine (NPY) - a major cardiac neuropeptide. Lancet 1983;i:1008-10.

${ }^{6} \mathrm{Gu}$ J, Polak JM, Allen JM, et al. High concentrations of a novel peptide, NPY, in the innervation of mouse and rat heart. J Histochem Cytochem (in press).

${ }^{7}$ Lundberg JM, Terenius L, Hökfelt T, et al. Neuropeptide Y (NPY)-like immunoreactivity in peripheral noradrenergic neurons and effects of NPY on sympathetic function. Acta Physiol Scand 1982;116:477-80.

${ }^{8}$ Ferri GL, Ali Rachedi A, Tatemoto K, Bloom SR, Polak JM. Neuropeptide-Y (NPY) immunoreactive innervation of the mammalian gastrointestinal tract. J Pathol 1983;140:173.

${ }^{9}$ Hökfelt T, Lundberg JM, Tatemoto K, et al. Neuropeptide Y (NPY) and FMRF-amide neuropeptide-like immunoreactivities in catecholamine neurons of the rat medulla oblongata. Acta Physiol Scand 1983;117:315-81.

${ }^{10}$ Allen JM, McGregor GP, Adrian TE, et al. Reduction of neuropeptide Y (NPY) in the rabbit iris-ciliary body after chronic sympathectomy. Exp Eye Res 1983;37:213-5.

"Terenghi G, Polak JM, Allen JM, Zhang SQ, Unger WC, Bloom SR. Neuropeptide Y-immunoreactive nerves in the uvea of guinea pig and rat. Neuroscience Letters 1983;42:33-8.

12 Polak JM, Bloom SR. Distribution of regulatory peptides in the respiratory tract of man and mammals. In: Bloom SR, Polak JM, Lindenlaub E, eds. Systemic role of regulatory peptides. Stuttgart: FK Schattauer Verlag, 1982: 241-69.

${ }^{13}$ Dey RD, Shannon WA, Said SI. Localisation of VIPimmunoreactive nerves in airways and pulmonary vessels of dogs, cats and human subjects. Cell Tiss Res 1981;220:231-8.

${ }^{14}$ Wharton J, Polak JM, Bloom SR, Will JA, Brown MR, Pearse AGE. Substance P-like immunoreactive nerves in mammalian lung. Investigative Cell Pathology 1979;2:3-10. is Wharton J, Polak JM, Bloom SR, et al. Bombesin-like immunoreactivity in the lung. Nature 1978;273:76970.

${ }^{16}$ Becker KL, Monaghan KG, Silva OL. Immunocytochemical localisation of calcitonin in Kulchitsky cells of the human lung. Arch Pathol Lab Med 1980;104:196-8.

17 Ghatei MA, Sheppard MN, O'Shaughnessy DJ, et al. Regulatory peptides in the mammalian respiratory tract. Endocrinology 1982;111:1248-54.

18 Trolle D. Age of foetus determined from its measures. Acta Obst Gynec Scand 1948;27:327-37.

${ }^{19}$ Patten BM. Age, growth and changes in external form of body: estimation of age and methods of measuring embryos. In: Patten BM, ed. Human embryology. New York: 1968:139-61.

${ }^{20}$ Loosli CG, Potter EL. Pre- and post-natal development of the respiratory portion of the human lung. Am Rev Respir Dis 1959;80:5-23.

${ }^{21}$ Bishop AE, Polak JM, Bloom SR, Pearse AGE. A new universal technique for the immunocytochemical localisation of peptidergic innervation. $J$ Endocrinol 1978; 77:25-6P (abstract).

22 Coons AH, Leduc EH, Conolly JM. Studies on antibody production. 1: A method for the histochemical demonstration of specific antibody and its application to a study of the hyperimmune rabbit. $J$ Exp Med 1955;102:49-60.

${ }^{23}$ Allen JM, Bircham PMM, Edwards AV, Tatemoto K, Bloom SR. Neuropeptide Y (NPY) reduces myocardial perfusion and inhibits the force of contraction of the isolated perfused rabbit heart. Regulatory Peptides 1983;6:247-53.

${ }^{24}$ Allen JM, Adrian TE, Tatemoto K, Polak JM, Hughes J, Bloom SR. Two novel related peptides. Neuropeptide Y (NPY) and Peptide YY (PYY) inhibit the contraction of electrically stimulated mouse vas deferens Neuropeptides 1982;3:71-7.

${ }^{25}$ Sheppard MN, Kurian SS, Henzen-Logmans SC, et al. Neuron-specific enolase and S-100: new markers for delineating the innervation of the respiratory tract in man and other mammals. Thorax 1983;38:333-40.

${ }^{26}$ Sheppard MN, Marangos PJ, Bloom SR, Polak JM. Neuron specific enolase: a marker for the early development of nerves and endocrine cells in the human lung. Life Sci 1984;3:265-71. 